\title{
Edaphic Factors Influencing the Control of Wyoming Big Sagebrush and Seedling Establish- ment of Crested Wheatgrass
}

\author{
GREG J. CLUFF, JAMES A. YOUNG, AND RAYMOND A. EVANS
}

\begin{abstract}
The physiographic position and taxonomic identity of soils of a Wyoming big sagebrush (A rtemisia tridentata spp. wyomingensis)/grassland community were determined. Surface soil materials from each identified soil were analyzed for a variety of chemical and physical properties. Areas of each soll were either burned, sprayed with 2,4-D [(2,4-dichlorophenoxy) acetic acid], or plowed for sagebrush control and seeded to crested wheatgrass (Agropyron desertorum cultivar Nordan). Spraying and plowing resulted in significantly $(p=0.05)$ different sagebrush mortalities of 75 and 62\% averaged over all solls with brush mortality being much higher on some soils than others. Burning resulted in $100 \%$ sagebrush mortality on all solls. Seedling establishment of crested wheatgrass was significantly higher on plowed than sprayed soils with 9 and 6 seedlings per meter of row, respectively. Soils of burned areas averaged 5 seedlings per meter of row on a dry year. Most seedlings were established on loamy soils regardless of the method of brush control. Multiple regression analyses of edaphic factors were used to develop equations predicting brush mortality and seedling establishment in sprayed and plowed areas. Soil series descriptions include data which could be used in making such predictions.
\end{abstract}

The Wyoming big sagebrush (Artemisia tridentata spp. wyomingensis) grassland community occupies at least $\mathbf{4 0}$ million hectares in the western United States (Tisdale et al. 1969). With the introduction of cattle to this community in the 1850's and heavy overgrazing in the 1880 's, much of the endemic perennial grass understory was

Authors are, respectively, range agronomist, University. of Nevada, and range scientists, USDA Agricultural Research Service, 920 Valley Road, Reno, Nev. 89512. This manuscript is submitted with the approval of the Director, Nevada Agricultural Experiment Station. Journal Series No. 375.

Manuscript received December 2, 1982. destroyed, leaving degraded, closed stands of sagebrush in many areas (Young et al. 1979a). Rehabilitation of the degraded sagebrush/grasslands began in the 1930's when R.L. Piemeisel demonstrated that one way to restore such lands was to remove the brush and establish perennial grasses (Piemeisel and Chamberlin 1936). Since that time, much research has gone into the development of better and more cost-effective technologies for the improvement of degraded sagebrush/grasslands.

Early recommendations for rangeland improvement were very generalized when addressing the question of what soils should be seeded. The sagebrush/grassland community was considered edaphically rather homogeneous for seeding purposes. Robertson and Kenneth (1943) recommended seeding areas "with annual precipitation in excess of 10 inches, with at least 2 or 3 inches falling during the spring growing season, and where there is good depth of productive soils." Plummer et al. (1955) recommended seeding areas of deep, fertile soils that were well supplied with organic matter. Heavy soils with good moisture-holding capacity were recommended more than lighter textured soils in areas of marginal precipitation. Saline soils were not recommended for seeding. Schwendiman (1955) recommended seeding where soil had good moisture-holding capacity, depth, and fertility to grow grass. Use of available soil surveys and land-use maps was advised.

More recent studies have been concerned with more precisely defining soil characteristics which affect seedling and stand establishment of crested wheat grass. Eckert et al. (1961) found differences in the stand establishment and herbage yield of crested wheatgrass on 3 adjacent but edaphically, topographically, and vegetationally different areas within the big sagebrush (Artemisia tridentata) community. The different productivities of the 3 areas were 
believed to be related to the moisture-holding capacity of the soils. Use of indicator species and general soil classifications was recommended for determining site potential for seeding with crested wheatgrass. Shown et al. (1969) did an extensive study relating crested wheatgrass yield to precipitation, cultural practices, and soil characteristics at 48 sites throughout the western United States. They concluded that success or failure of seeding was the result of complex interactions of climate, soil, treatment methods, and grazing management. Simple correlation coefficients were very small when crested wheatgrass yields were compared with any of the measured soil, natural vegetation, or precipitation values. Their data indicated that moisture-holding capacity was the single soil property best correlated with stand yield. Wood (1976) found that emergence of crested wheatgrass was lower in interspace soils with vesicular crusts between shrub mounds, than in noncrusting coppice soils beneath shrubs. Seedlings emerging in crusted, interspace soils showed a high degree of stress, as measured by morphological characteristics, compared with seedlings emerging in noncrusted, coppice soils. Wood et al. (1982) concluded that descriptive criteria for selecting a successful seeding site in the sagebrush/grassland community include the density, size, and vigor of sagebrush which could be used as an indicator of the percentage of coppice and interspace and therefore the severity of vesicular crusting. Better crested wheatgrass emergence in noncrusted, coppice soils than in interspace soils was thought to be related to more favorable texture, structure, and moisture-holding characteristics.

The United States Department of Agriculture Soil Conservation Service (SCS) has commonly used soil survey data as means of determining land use potential of rangelands (Anonymous 1976). The concept of range site has been developed as a basis of site suitability for seeding based upon a gross summary of precipitation, topography, elevation, native vegetation, and soils (Vallentine 1971). Soil factors used in site determinations include texture of the surface, percentage of coarse fragments, depth to a restrictive layer, depth to an abrupt textural change, electrical conductivity of the top $18 \mathrm{~cm}$, depth of root zone, available water-holding capacity of the top $18 \mathrm{~cm}$, and tendency toward vesicular crusting (Anonymous 1971). However, interpretation of the effects of these soil characteristics on seeding suitability is completely subjective and the relative importance of each factor in determining seeding suitability has not been determined. A site is simply classified as good, fair, poor, or very poor for seeding. Successful seedings can be expected 7 out of 10 years on good sites and 3 years out of 10 on very poor sites. Several species could be planted on good sites, but only the most drought-tolerant species should be planted on poor or very poor sites.

Few studies have been concerned with the effects of specific soil properties on sagebrush control. Recommendations for control have usually been based upon practical considerations such as economics, topography and terrain, effects on desired species, and availability of equipment (Vallentine 1971). However, soil moisture at the time of treatment is one factor which has been related to sagebrush control, either by spraying or plowing. Cook (1963) reported poor sagebrush mortality using 2,4-D when soil in the upper $60 \mathrm{~cm}$ of a silty clay loam was below $12 \%$. He interpreted this percentage moisture to be equivalent to $15.5,13.5,12.5,10.5$, and $5.5 \%$ moisture for clay, loam, clay loam, silt loam, and sandy loam soils, respectively. Soil moisture at the day of herbicide application was not directly correlated with sagebrush mortality. Bleak and Miller (1955) found that summer plowing in Nevada, when the soil was dry and firm, killed more mature sagebrush plants than spring plowing, when the soil was moist and compactible. Pechanec et al. (1954) observed that plowing or disking, correctly done, would kill 70 to $90 \%$ of sagebrush; however, on heavy, compact, dry soils, it would probably be necessary to plow twice.

The purpose of this experiment was to compare 3 standard range improvement techniques applied to sites with variable soil features in the same geographical area for their effects on Wyoming big sagebrush mortality and seedling establishment of crested wheatgrass. We believed that there are easily determined soil characteristics that the land manager could use in quantitatively determining the probability of success or failure of a given range improvement technique to control sagebrush and establish seedlings of crested wheatgrass.

\section{Methods}

The experimental area was located at the University of Nevada Gund Ranch Research and Demonstration Center in Grass Valley, central Nevada. The ranch contains several thousand hectares of degraded sagebrush/grassland on alluvial fans along the base of the Simpson Park Mountains. Wyoming big sagebrush is the dominant brush species in the experimental area with a sparse understory of Sandberg bluegrass (Poa secunda), squirreltail (Sitanion hystrix), Indian ricegrass (Oryzopsis hymenoides), and downy brome (Bromus tectorum). A century of livestock grazing has greatly reduced the native perennial grass portion of the plant community. Thurber's needlegrass (Stipa thurberiana) and bluebunch wheatgrass (Agropyron spicatum) may have once occurred in specific plant communities on the alluvial fans (Young and Evans 1980). This area was considered poor for rangeland seeding; crested wheatgrass establishment could be expected only 5 years out of 10 (personal communication of R.A. Foster, USDI/BLM, Elko, Nev.). Average annual precipitation ranges from 20 to $36 \mathrm{~cm}$ with most moisture occurring in the winter and early spring (Houghton et al. 1975). Precipitation for the 2 years of the study was 26 and $20 \mathrm{~cm}$ from July 1 to June 30,1979 and 1980 , with 13 and $18 \mathrm{~cm}$ occurring in the winter-spring of 1979 and 1980 , respectively.

Aerial photographs of the experimental area were used to delineate landforms which served as the basis for determining boundaries for taxonomic identification of the soils. Soil horizons were described to a depth of $2 \mathrm{~m}$ in each landform area and the soils were identified taxonomically (Anonymous 1975). Four soils occupying the major portion ( $>95 \%$ ) of the study area were tentatively identified. Soil samples were taken to a depth of $10 \mathrm{~cm}$ in the interspace of each of the 4 soils in 5 locations along the 6-km length of the study area. The samples were analyzed for those properties which would best differentiate specific soils in terms of their surface characteristics. The soils were analyzed for percent gravel by sieving through a 2-mm screen, percent sand, silt, and clay using the method of Bouyoucos (1962); percent organic matter using the method of Walkley and Black (Black 1965b); relative infiltration rate of $5 \mathrm{~cm}$ of water using a double ring infiltrometer in situ (Black 1965a) with 7.6 and $20 \mathrm{~cm}$ inside and outside diameter rings; electrical conductivity of the saturated paste extract using a conductivity meter; nitrate using a digital ion analyzer with a nitrate probe; and relative dry force of penetration using a hand-held force indicator with a $0.5 \mathrm{~cm}$ diameter by $0.5 \mathrm{~cm}$ long cone-shaped tip. Data were analyzed using discriminate analysis (Nie et al. 1970) in order to statistically separate the soils based on these properties. The 4 soils will be described in detail in the results section of this paper. The percentage area covered by coppice and interspace was determined for each soil along four 50-m transects by the lineintercept method (Phillips 1959).

In the spring and summer of 1979, twelve 16-ha exclosures were established in this area. The fenced areas were placed so as to include portions of the $\mathbf{4}$ major identified soils plus small inclusions of different soils. Treatments for range improvement involved 3 methods of brush control and 2 methods of seeding. Brush control methods were: (a) spraying with $3.3 \mathrm{~kg} / \mathrm{ha} 2,4-\mathrm{D}$ low volatile ester, (b) brushland plowing in 2 directions, and (c) burning. Seeding methods were: (a) seeding crested wheatgrass cultivar Nordan with a regular rangeland drill, and (b) seeding crested wheatgrass with a deep-furrow rangeland drill. The treatments were located within the fenced areas such that each treatment (method of brush control and seeding) covered at least 1 ha of each 
of the 4 soils. Herbicidal brush control was done in early May 1979. A modified ground sprayer for sagebrush rangelands (Young et al. $1979 \mathrm{~b}$ ) was used to apply $3.3 \mathrm{~kg} / \mathrm{ha}$ of $2,4-\mathrm{D}$ low volatile ester to large portions of each soil (minimum of $5 \mathrm{ha}$ ). The herbicide was applied in water at 105 liters/ha. Other areas of each soil (minimum of 2.5 ha) were plowed in 2 directions using a brushland plow (Anonymous 1968) at different times from May through August 1979 for sagebrush control. Treated areas were planted with crested wheatgrass at $9 \mathrm{~kg} /$ ha in October 1979 using a standard rangeland drill with $30-\mathrm{cm}$ row spacing, and using a modified deep-furrow rangeland drill (Asher and Eckert 1979) with 50-cm row spacing. At least one third of each soil-brush control treatment was seeded using the modified deep-furrow rangeland drill. The prescribed burn treatment was conducted in August 1980. At the time of burning, relative humidity was less than $10 \%$, air temeprature was $35^{\circ} \mathrm{C}$, and wind speed was $24 \mathrm{~km} / \mathrm{hr}$. The burned treatment was seeded in October 1980 using standard and modified drills. It was only practical to seed 2 of the major soils in the burned treatment.

In May 1980, a second set of surface soil samples (top $10 \mathrm{~cm}$ ) were taken in 5 locations in each of the 4 major defined soils and in the small inclusions of other soils in the seeded areas. Sampling was stratified by coppice and interspace where such areas could be discerned. Some soils did not have evident coppice and interspace, and plowing destroyed distinguishing evidence of coppice and interspaces in other soils. The samples were analyzed for the same properties and in the same manner as the first set of samples that were used to statistically differentiate the major soils.

In July 1980, percentage brush mortality was determined in 4 randomly placed 2 by $50-\mathrm{m}$ transects for each soil type in each brush control treatment. Seedling establishment of crested wheatgrass was determined by counting the number of seedlings in 10 random samples consisting of $1-\mathrm{m}$ row in each soil, brush control treatment, and drill treatment. Sampling was stratified by coppice and interspace where such areas were discernible. The yield, frequency, and percentage cover of downy brome was determined by clipping 10 plots, $0.1 \mathrm{~m}^{2}$ in area, by the step-point method (Evans and Love 1957), and estimating ground cover of ten $0.25-\mathrm{m}^{2}$ plots, respectively, on each soil in each brush control treatment, and in adjacent untreated areas.

In March 1981, gypsum moisture blocks were buried 15 and $40-\mathrm{cm}$ below the soil surface in 5 coppice and interspace locations of each soil and read at 2-week intervals throughout the growing season. The moisture blocks were placed in areas of complete sagebrush control. The moisture blocks were used to measure relative differences in the drying rates of each soil after winterspring precipitation ceased in late spring.

In July 1981, biological sampling was done in the burned treatment. The same parameters were sampled by the same procedures used for the plowed and sprayed treatments the previous year.

The data were analyzed statistically using analysis of variance and simple and multiple linear regression. Statistical differences between means resulting from effects of sprayed and plowed treatments and the $\mathbf{4}$ major soils on sagebrush mortality and seedling establishment of crested wheatgrass were determined using analysis of variance and Duncan's multiple range test. Relationships between specific edaphic factors and big sagebrush mortality and seedling establishment of crested wheatgrass were determined using simple and multiple linear regression. Means of 5 samples per soil were used in the regression. By using data from coppices, interspaces, the 4 major soils, and other soil inclusions, 8 and 9 means were used in regressions in which seedling establishment was correlated with edaphic factors in sprayed and plowed treatments, respectively. By using data from the 4 major soils and other soil inclusions, 6 means were used in regressions in which sagebrush mortality was correlated with edaphic factors in both sprayed and plowed treatments. Data of brush mortality and seedling establishment from the prescribed burning treatment were analyzed separately because this treatment was conducted in a different year than were spraying and plowing.

\section{Results and Discussion}

Soils

Four distinct landforms were defined: (a) alluvial fans occupying $33 \%$ of the study area; (b) inset fans, $28 \%$; (c) offshore bars, $24 \%$; and (d) lagoons, 15\% (Peterson 1981). Alluvial fans were formed at the openings of each major canyon along the Simpson Park escarpment. During the Pleistocene, pluvial Lake Gilbert filled Grass Valley to $1,870 \mathrm{~m}$ above sea level creating a beach across the base of the alluvial fans (Mifflin and Wheat 1979). Wave action formed a series of offshore bars and lagoons shoreward of the bars as the lake receded during the interglacial period (Born 1972). Lake Gilbert dried during the early Holocene leaving a large finetextured playa (Motts 1970) on the valley floor. Many alluvial fans were cut off from further stream flow because of channeling of the limited water sources into valleys between the fans or into streambeds.

Because of this physiographic development, the 4 landforms developed distinct soils. As Lake Gilbert receded to successively lower stages, lagoons were separated from the main body of the lake by their associated offshore bars. Lagoons, being topographical depressions, accumulated silt and clay which washed off the alluvial fans. Offshore bars, still being washed by waves of the lake, became highly gravelly. After Lake Gilbert completely dried, aeolian material from the playa was deposited on the alluvial fans adding very fine sand, silt, and clay to the upper horizons. Areas such as inset fans which were still subject to stream washing were purged of fine-textured particles during periods of runoff and maintained high gravel contents and course textures.

This geomorphic history is reflected in the kinds of soil dominating each landform today. Alluvial fans, inset fans, offshore bars, and lagoons are occupied by Abgese loam, Zineb very gravelly sandy loam, McConnel gravelly sandy loam, and Bubus silty loam, respectively (Table 1). Abgese is a soil series belonging to the Xerollic Haplargid subgroup. These soils have a well-developed soil profile, a Bt horizon which is permeable to moisture, and relatively more organic matter and moisture than the Typic subgroup. Zineb is a series belonging to the Durixerollic Camborthid subgroup. These soils have a subhorizon with weak cementation by silica which is still permeable to moisture, and have relatively more organic matter and moisture than the typic subgroup. They are probably soils of recent formation. McConnel is a series belonging to the Xerollic Camborthid subgroup. These soils also have relatively more organic matter and moisture than the Typic subgroup and are also probably soils of recent formation. Bubus is a series belonging to the Durorthidic Torriorthent subgroup. Soils of this subgroup are typified by little or no evidence of development of diagnostic horizons. They are primarily formed by recent depositional processes. They are dry or salty, and have weak cementation with silica in one or more horizons. All soils except Zineb have some degree of vesicular crusting (Table 1).

Discriminate analysis of the interspace soil surface samples showed that the original physiographic delineation of the soils based on the aerial photographs was valid, in that samples from within each landform were not statistically different, but samples compared among landforms were statistically different $(p=0.05)$ based on the properties which were measured. Discriminate functions correctly classified the surface soil samples into the landforms and soils from which they were obtained $95 \%$ of the time. Percent gravel and silt were the most important features separating the soils. The soil series Abgese and McConnel were the most difficult to separate from each other, whereas Zineb and Bubus were the easiest to separate. These results indicate that geomorphological development of the soils within each landform produced surface soils with very similar physical and chemical properties (Table 2).

Surface soil textures ascribed to each soil series (phase criteria) from profile descriptions were not always the same as those ascribed to each landform from samples used in the discriminate 
Table 1. Pertinent data from pedon descriptiona for soil series in the experimental area at Grass Valley, Nevada.

\begin{tabular}{|c|c|c|c|c|c|}
\hline $\begin{array}{l}\text { Series, slope } \\
\text { (landform) }\end{array}$ & Horizon & $\begin{array}{l}\text { Depth } \\
\text { (cm) }\end{array}$ & Texture & Dry consistence ${ }^{2}$ & Pores $^{3}$ \\
\hline $\begin{array}{l}\text { Abgese, } 5-10 \% \\
\text { (alluvial fan) }\end{array}$ & $\begin{array}{r}\mathrm{Al} \\
\mathrm{A} 2 \\
2 \mathrm{Btl} \\
3 \mathrm{Bt} 2 \\
3 \mathrm{~Bq}\end{array}$ & $\begin{array}{c}0-13 \\
13-33 \\
33-48 \\
48-88 \\
88-123\end{array}$ & $\begin{array}{r}1 \\
1 \\
\mathrm{cl} \\
\text { vgrcl } \\
\text { exgrl }\end{array}$ & $\begin{array}{l}\text { so } \\
\text { sh } \\
\text { h } \\
h \\
h\end{array}$ & $\begin{array}{c}2 v f v \\
1 v f v \\
0 \\
0 \\
0\end{array}$ \\
\hline $\begin{array}{l}\text { Zineb, } 5-15 \% \\
\text { (inset fan) }\end{array}$ & $\begin{array}{r}\mathrm{Al} \\
\mathrm{A} 2 \\
\mathrm{BW1} \\
\mathrm{BW} 2 \\
\mathrm{Cl} \\
2 \mathrm{C} 2 \\
3 \mathrm{C} 3\end{array}$ & $\begin{array}{c}0-5 \\
5-18 \\
18-33 \\
33-40 \\
40-85 \\
85-110 \\
110-180\end{array}$ & $\begin{array}{r}\text { vgrsl } \\
\text { vgrl } \\
\text { vgrsl } \\
\text { vgrsl } \\
\text { vgrl } \\
\text { grl } \\
\text { exgrsl }\end{array}$ & $\begin{array}{l}\text { so } \\
\text { so } \\
\text { so } \\
\text { so } \\
\text { sh } \\
\text { sh } \\
\text { so }\end{array}$ & $\begin{array}{r}0 \\
3 v f \\
0 \\
0 \\
0 \\
0 \\
0\end{array}$ \\
\hline $\begin{array}{l}\text { McConnel, 4-8\% } \\
\text { (offshore bar) }\end{array}$ & $\begin{array}{r}\mathrm{Al} \\
\mathrm{A} 2 \\
\mathrm{BW} \\
2 \mathrm{Cl} \\
3 \mathrm{C} 2 \\
3 \mathrm{C} 3\end{array}$ & $\begin{array}{c}0-5 \\
5-18 \\
18-38 \\
38-63 \\
63-90 \\
90-163\end{array}$ & $\begin{array}{r}\text { grsl } \\
1 \\
\text { grl } \\
\text { vgrsl } \\
\text { exgrsl } \\
\text { exgrs }\end{array}$ & $\begin{array}{l}\text { so } \\
\text { so } \\
\text { sh } \\
\text { sh } \\
\text { lo } \\
\text { lo }\end{array}$ & $\begin{array}{c}3 \mathrm{vfv} \\
3 \mathrm{vfv} \\
3 \mathrm{vf} \\
0 \\
0 \\
0\end{array}$ \\
\hline $\begin{array}{l}\text { Bubus, 0-2\% } \\
\text { (lagoon) }\end{array}$ & $\begin{array}{r}\text { Al } \\
\text { A2 } \\
\text { Bgkl } \\
\text { Bgk2 } \\
\text { Bgk3 } \\
2 \mathrm{Ck} 4 \\
3 \mathrm{Ck} 5\end{array}$ & $\begin{array}{c}0-8 \\
8-18 \\
18-30 \\
30-48 \\
48-75 \\
75-115 \\
115-163\end{array}$ & $\begin{array}{r}\text { sil } \\
1 \\
1 \\
\text { fsl } \\
\text { vfsl } \\
\text { vfsl } \\
\text { sicl }\end{array}$ & $\begin{array}{l}\text { sh } \\
\text { sh } \\
\text { sh } \\
\text { sh } \\
\text { sh } \\
\text { so } \\
\text { sh }\end{array}$ & $\begin{array}{c}3 \mathrm{vfv} \\
3 \mathrm{vfv} \\
3 \mathrm{vfv} \\
0 \\
0 \\
0 \\
0\end{array}$ \\
\hline
\end{tabular}

Texture abbreviations: $1=$ loam; $\mathrm{cl}=$ clay loam; $\mathrm{sl}=$ silt loam; sicl = silty clay loam; $\mathrm{v}=\mathrm{very} ; \mathrm{gr}=\mathrm{gravelly}$; ex $=\mathrm{extremely} ; \mathrm{f}=$ fine; $\mathrm{vf}=\mathrm{very}$ fine.

2Dry consistence abbreviations; so $=$ soft; $s h=$ slightly hard; $h=$ hard; lo $=$ loose.

Pores abbreviations: $1=$ few; student = common; $3=$ many; vf $=$ very fine; $v f v=$ very fine vesicular.

analysis. Alluvial fan, offshore bar, and lagoon surface textures were identified as a loam, gravelly sandy loam, and silty loam, respectively, from profile descriptions, and as a sandy loam, gravelly loam, and clay loam, from the average of the discriminate analysis samples (Table 1 and 3). This disparity occurred because soil properties obtained from profile descriptions were not averages, but constituted single samples. Because the surface layer is the most active and variable layer of the soil profile, land managers should recognize this variability when using survey data for making seeding-suitability recommendations.

\section{Wyoming Big Sagebrush Control}

Spraying and plowing resulted in significantly $(p=0.05)$ different mortalities of 75 and $62 \%$, respectively, averaged over the 4 major soils. Numerically higher brush control was achieved by spraying rather than by plowing on 3 of the soils, but neither method worked well on the Bubus soils (Table 3). Significantly higher brush mortality was achieved by spraying $(87 \%)$ compared with plowing
(64\%) on Abgese soils. Sagebrush was easiest to control on Zineb soils with $98 \%$ mortality by spraying and $84 \%$ by plowing. Sagebrush control was more difficult on Bubus soils with $46 \%$ mortality by spraying and $48 \%$ by plowing. Burning killed $100 \%$ of the sagebrush on all soils. On Bubus soils, small infestations of greasewood (Sarcobatus vermiculatus) and salt rabbitbrush (Chrysothamnus nauseosus ssp. consimilis) resprouted.

Sagebrush mortality in sprayed areas was positively correlated with gravel and sand content of soils, and negatively correlated with silt and clay (Table 4). The finer the soil texture, the lower the sagebrush control by spraying. Possibly, sagebrush control by spraying was affected by available soil moisture resulting from the interaction between precipitation and soil texture. Multiple regression analysis correlated $(p=0.05)$ sand, silt, clay, and infiltration rate with soil moisture potential $(R=0.93)$. These results agree with those of Cook (1963) and indicated that available soil moisture is needed at time of spraying of 2,4-D for sagebrush control. Results

Table 2. Physical and chemical properties of interspace surface samples of soil series from the study area in Grass Valley, Nevada1.

\begin{tabular}{|c|c|c|c|c|c|c|c|c|c|c|c|c|}
\hline \multirow{2}{*}{$\begin{array}{l}\begin{array}{l}\text { Series } \\
\text { (landform) }\end{array} \\
\text { Zineb } \\
\text { (inset fan) }\end{array}$} & \multirow{2}{*}{$\begin{array}{c}\begin{array}{c}\text { Gravel } \\
(\%)\end{array} \\
60 a\end{array}$} & \multirow{2}{*}{$\begin{array}{c}\begin{array}{c}\text { Sand } \\
(\%)\end{array} \\
26 \mathrm{~b}\end{array}$} & \multirow{2}{*}{$\begin{array}{c}\text { Silt } \\
(\%)\end{array}$} & \multirow{2}{*}{$\begin{array}{c}\begin{array}{c}\text { Clay } \\
(\%)\end{array} \\
4 b\end{array}$} & \multirow{2}{*}{$\begin{array}{c}\begin{array}{c}\text { Organic } \\
\text { matter } \\
(\%)\end{array} \\
5.7 \mathrm{a}\end{array}$} & \multirow{2}{*}{$\frac{\begin{array}{r}\text { Nitrate } \\
(\mathrm{ppm})\end{array}}{24 \mathrm{~b}}$} & \multirow{2}{*}{$\begin{array}{c}\begin{array}{c}\text { Pene- } \\
\text { tration } \\
(\mathrm{kg})\end{array} \\
\text { lb }\end{array}$} & \multirow{2}{*}{$\frac{\begin{array}{c}\mathrm{EC} \\
(\mathrm{mmhos} / \mathrm{cm})\end{array}}{.2 \mathrm{a}}$} & \multirow{2}{*}{$\begin{array}{c}\begin{array}{c}\text { Infiltra- } \\
\text { tion } \\
\text { rate } \\
(\mathrm{cm} / \mathrm{hr})\end{array} \\
48 \mathrm{a}\end{array}$} & \multicolumn{2}{|c|}{$\begin{array}{c}\text { May } 1981 \\
\text { soil } \\
\text { moisture } \\
\text { potential } \\
\text { (-bars) } \\
15 \mathrm{~cm} 40 \mathrm{~cm}\end{array}$} & \multirow{2}{*}{$\begin{array}{c}\begin{array}{c}\text { Coppice } \\
(\%)\end{array} \\
-\end{array}$} \\
\hline & & & & & & & & & & $1.2 \mathrm{a}$ & $0.5 a$ & \\
\hline $\begin{array}{l}\text { Abgese } \\
\text { (alluvial fan) }\end{array}$ & $32 c$ & $39 \mathrm{a}$ & $21 b$ & $7 \mathbf{b}$ & $1.7 \mathrm{~b}$ & $24 b$ & $3 b$ & $.2 \mathrm{a}$ & $\mathbf{3 b}$ & $2.8 \mathrm{a}$ & $0.5 \mathrm{a}$ & $54 a$ \\
\hline $\begin{array}{l}\text { McConnel } \\
\text { (offshore bar) }\end{array}$ & $47 b$ & $26 \mathrm{~b}$ & $19 b c$ & $7 b$ & $1.6 \mathrm{~b}$ & $39 a$ & $3 b$ & da & $2 b$ & $0.7 \mathrm{a}$ & $1.6 \mathrm{a}$ & $51 a$ \\
\hline $\begin{array}{l}\text { Bubus } \\
\text { (lagoon) }\end{array}$ & $12 d$ & $27 \mathrm{~b}$ & $36 a$ & $25 \mathrm{a}$ & $1.3 \mathrm{~b}$ & $20 \mathrm{~b}$ & $7 \mathbf{a}$ & $.3 a$ & $.5 c$ & $3.4 \mathrm{a}$ & $1.7 \mathrm{a}$ & $42 b$ \\
\hline
\end{tabular}

${ }_{1}^{1}$ Means within columns followed by the same letter are not significantly different at the 0.05 probability level as determined by Duncan's multiple range test. 
Table 3. Wyoming big sagebrush control and seedling establishment of crested wheatgrass as related to soil, landforms, and surface soil texture at Grass Valley, Nevada.1

\begin{tabular}{|c|c|c|c|c|c|}
\hline \multirow[b]{2}{*}{$\begin{array}{l}\text { Series } \\
\text { (landform) }\end{array}$} & \multirow[b]{2}{*}{ Surface texture } & \multicolumn{2}{|c|}{ Brush mortality } & \multicolumn{2}{|c|}{ Seedling establishment } \\
\hline & & Spray & Plow & $\begin{array}{c}\text { Spray } \\
\text { se }\end{array}$ & Plow \\
\hline $\begin{array}{l}\text { Zineb } \\
\text { (inset fan) }\end{array}$ & $\begin{array}{l}\text { very gravelly } \\
\text { sandy loam }\end{array}$ & $98 \mathrm{a}$ & $84 a$ & $8 \mathrm{bc}$ & $11 \mathrm{~b}$ \\
\hline $\begin{array}{l}\text { Abgese } \\
\text { (alluvial fan) }\end{array}$ & sandy loam & $87 a$ & $64 \mathrm{bc}$ & $6 c$ & $17 \mathbf{a}$ \\
\hline $\begin{array}{l}\text { McConnel } \\
\text { (offshore bar) }\end{array}$ & gravelly loam & $67 b$ & $52 \mathrm{bd}$ & $10 \mathrm{~b}$ & $6 c$ \\
\hline $\begin{array}{l}\text { Bubus } \\
\text { (lagoon) }\end{array}$ & clay loam & $46 d$ & $48 \mathrm{~cd}$ & ld & ld \\
\hline
\end{tabular}

'Means within a variable (brush mortality or seedling establishment) followed by the same letter are not significantly different at the 0.05 probability level as determined by Duncan's multiple range test.

of this study also indicate that available soil moisture is a function of soil texture as it affects infiltration and soil matric potential as well as a function of precipitation.

Sagebrush mortality in plowed areas was positively correlated with gravel and infiltration rate, and negatively correlated with silt, clay, nitrate, and force of penetration (Table 4). Mortality was also positively correlated with soil moisture at $15 \mathrm{~cm}$ depth; however, this was probably the result of the relationship among brush mortality, soil moisture, and soil texture properties. These results suggest that the coarser the soil texture, the softer the soil, and the more effective the removal of crowns of sagebrush by plowing. This agrees with observations by Pechanec et al. (1954) that heavy compact soils should be plowed twice for good brush control. However, plowing twice in this study did not result in good sagebrush control in any soil except the Zineb soils (Table 3). The SCS soil survey parameter which best reflects these results is that of dry consistence (Table 1). Only the Zineb soils had a dry consistence rating of soft below $18 \mathrm{~cm}$, while the other soils were rated as slightly hard in one or more layers below $18 \mathrm{~cm}$.

Multiple regression analysis showed that sagebrush mortality in sprayed and plowed areas could be predicted from edaphic factors. Percent sand and silt were used to predict brush mortality by spraying with the following equation:

$$
\text { Mortality }(\%)=.24 \times \text { sand }(\%)-.79 \times \text { silt }(\%)+88.9
$$

The $R$ for the regression was $0.97(p=0.05)$. Force of penetration, percent sand, and percent silt, in decreasing order of importance, were used to predict brush mortality by plowing with the following equation:

Mortality $(\%)=-4.3 \times$ force of penetration $(\mathbf{k g})+.66 \times$ sand $(\%)-.13 \times$ silt $(\%)+71.8$

The $R$ for the regression was $0.99(p=0.05)$. Good correlations were found if edaphic factors from coppice or interspace were used as independent variables, although data for the above regressions are from interspace samples only. These results reflect the previously mentioned effects of soil texture on soil moisture availability and force of penetration.

Soil survey data collected by SCS does not include force of penetration. Dry consistence is a qualitative property which is related to force of penetration, however, and could be quantified for use in mathematical models predicting brush mortality by plowing.

\section{Seedling Establishment}

Seedling establishment of crested wheatgrass averaged 6 plants per meter of row on the 4 major soils with sagebrush control by spraying of 2,4-D and 9 plants per meter of row with plowing $(p=0.05)$. Burning and seeding averaged 4.5 seedlings per meter of row with 2 seedlings per meter establishing on Zineb soil and 7 seedlings per meter on Abgese soil, but the seedling year for this treatment was drier than with the sprayed and plowed treatments. Wood et al. (1982) found that plowing reduced emergence but increased the frequency of established crested wheatgrass plants in areas with vesicular crusting soils. They attributed the beneficial effects of plowing to improved soil tilth, aeration, porosity, and microtopography which could increase the quantity of water percolating into the soil. However, in this study, increased emergence of crested wheatgrass seedlings resulted from plowing compared to spraying. Possibly, plowing was advantageous for increased emergence because coppice soils were mixed with those in the interspaces to make overall improvement for seedling growth.

However, seedling establishment was not higher with plowing on every soil compared to spraying (Table 3 ). Significantly ( $p=0.05$ ) higher seedling establishment resulted from spraying on McConnel soils. Plowing and spraying resulted in 17 and 6 seedlings per meter of row for Abgese soils and 6 and 10 seedlings per meter of row for McConnel soils, respectively. Abgese soils and McConnel soils were the most alike with respect to the measured edaphic properties (Table 2). However, the top $40 \mathrm{~cm}$ of Abgese

Table 4. Simple correlation coefficients between soil surface properties and Wyoming bis sagebrush mortality or seedling eatablishment of crested wheatgrass as affected by spraying or plowing.1

\begin{tabular}{|c|c|c|c|c|c|c|c|c|c|c|}
\hline Dependent variable & $\begin{array}{c}\text { Gravel } \\
(\%)\end{array}$ & $\begin{array}{c}\text { Sand } \\
(\%)\end{array}$ & $\begin{array}{l}\text { Silt } \\
(\%)\end{array}$ & $\begin{array}{l}\text { Clay } \\
(\%)\end{array}$ & $\begin{array}{c}\text { O.M. } \\
(\%)\end{array}$ & $\begin{array}{c}\text { I.R. } \\
(\mathrm{cm} / \mathrm{hr})\end{array}$ & $\begin{array}{c}E C \\
(\mathbf{S} / \mathrm{m})\end{array}$ & $\begin{array}{c}\mathrm{NO}^{3} \\
(\mathrm{ppm})\end{array}$ & $\begin{array}{r}\text { PN } \\
\text { (kg) }\end{array}$ & $\begin{array}{c}\mathbf{\Psi s} \\
\text {-bars) }\end{array}$ \\
\hline \multicolumn{11}{|l|}{ Brush control } \\
\hline Spray & $+.86^{*}$ & $+.74^{*}$ & $-.95 * *$ & $-.84 * *$ & +.69 & +.68 & -.69 & -.47 & -.54 & +.60 \\
\hline Plow & $+.82^{\star}$ & $+.26 *$ & $-.79 *$ & $-.97 * *$ & $+.83^{*}$ & $+.88^{*}$ & -.24 & $-.96 * *$ & $-.82^{*}$ & +.79 \\
\hline \multicolumn{11}{|c|}{ Seedling establishment } \\
\hline Spray & +.02 & $+.46^{*}$ & $-.52 *$ & -.22 & +.16 & +.12 & $-.46^{*}$ & $+.60^{*}$ & -.07 & $+.79^{*}$ \\
\hline Plow & $+.57 *$ & $+.57^{*}$ & $-.64^{\circ}$ & $-.70^{*}$ & -.01 & -.07 & $-.65^{*}$ & -.12 & -.10 & +.12 \\
\hline
\end{tabular}

'Means of 5 samples. O.M. = organic matter, I.R. = infiltration rate, EC = electrical conductivity, NO3 = nitrate, PN $=$ penetration, $\Psi s \approx$ soil moisture potential, May 1981, at 15 and $\mathrm{cm}$ for seedling establishment and brush control, respectively. ${ }^{*}=$ significant at 0.05 probability level, $* *=$ significant at 0.01 probability level. 
soils were finer textured than those of McConnel soils (Table 1). Fine soil texture seemingly is related to the differential effects of plowing and spraying in terms of infiltration and available soil moisture. Possibly, there is a range of silt content within which plowing improves aeration, porosity, and microtopography for seedling establishment.

Neither spraying or plowing resulted in satisfactory seedling establishment on Bubus soils; either method yielded an average of 1 seedling per meter of row. Five plants per square meter is considered good stand establishment in the Intermountain region (Cook et al. 1967). With the row spacing of the standard rangeland drill this would equal about 2 plants per meter of row, so only on the Bubus soils was seedling establishment unsatisfactory. Wein and West (1971) found poor seedling establishment of crested wheatgrass in bottoms of gully plugs where ponding of runoff water resulted in fine-textured, flood prone areas similar to lagoons (Bubus soils). They attributed high seedling mortality to drowning and soil heaving which broke off seedlings at the soil surface. The Bubus soils showed the greatest degree of vesicular crusting as indicated by the depth of very fine vesicular pores (Table 1). Wood et al. (1978) demonstrated that vesicular crusting formed in soils with high silt and low organic matter content, and that crusting reduced infiltration rate and increased stress on emerging seedlings. They showed that crusting was greatest on interspace soils. In this study, lagoon soils had the least percentage of coppice and, conversely, the greatest percentage of interspace (Table 2). Therefore, poor seedling establishment on Bubus soils can probably be attributed to the greater degree of vesicular crusting as compared with the other soils.

Seedling establishment of crested wheatgrass in sprayed areas was positively correlated with soil moisture potential, nitrate, and sand, and negatively correlated with silt and electrical conductivity. Seedling establishment in plowed areas was positively correlated with gravel and sand, and negatively correlated with silt, clay, and electrical conductivity (Table 4). Why seedling establishment in plowed areas was not significantly correlated with soil moisture potential is not known. Perhaps mixing of coppice and interspace in plowed areas mitigated the effects of soil factors, like infiltration rate, on moisture potential. Silt and electrical conductivity were negatively correlated and sand was positively correlated with seedling establishment in both sprayed and plowed soils (Table 4). This indicates that crested wheatgrass seedlings survived better in welldrained, nonsaline soils. It must be noted that the correlations were for variables within the limits measured for each soil and cannot be extrapolated to greater or lesser amounts. For example, seeding establishment of crested wheatgrass was correlated ( $r=0.79)$ with average May soil moisture potential in sprayed areas. Moisture potentials ranged from -3.4 to -0.4 bars and seedling establishment ranged from 0 to 19.5 seedlings per meter of row. Greater crested wheatgrass seedling establishment could not be expected in soils averaging higher moisture potentials than -0.4 bars. the same is true for other variables such as percent sand and silt.

Multiple regression analysis relating seedling establishment in sprayed and plowed areas to edaphic factors showed that seedling establishment could be predicted. With the following equation, nitrate, electrical conductivity, percent silt and percent clay in decreasing order of importance, were used to predict seedling establishment on soils following brush control by spraying:

Establishment (seedlings $/ \mathrm{m}$ of row) $=6.6 \times$ nitrate $(\mathrm{ppm})-4.9 \times \mathrm{EC}$ $(\mathrm{mmhos} / \mathrm{cm})-0.25 \times$ silt $(\%)+0.73 \times$ clay $(\%)+9.6$

The $R$ for the regression was $0.96(p=0.05)$. Percent clay, infiltration rate, and percent silt, in decreasing order of importance, were used to predict seedling establishment on plowed soils with the following equation:

Establishment (seedlings $/ \mathrm{m}$ of row) $=0.56 \times$ clay $(\%)-2 \times$ infiltration rate $(\mathrm{cm} / \mathrm{hr})-0.38 \times$ silt $(\%)+22.5$

The $R$ for the regression was $0.81(P=0.05)$. Lower predictability for seedling establishment on plowed soils probability reflected the vari- able effects within each soil series of mixing coppice, interspace, and subsurface horizons.

Significantly more seedlings $(p=0.05)$ were established on coppice than interspace soils. Seedling establishment averaged 14 and 5 seedlings per meter of row on coppice and interspace soils, respectively. Coppice and interspace were not well developed on Zineb soils and were not differentiated on those soils. On the other soils, where coppice and interspace were evident, coppice always produced significantly more seedlings than interspace. Abgese, McConnel, and Bubus soils averaged 17, 20, and 6 seedlings per meter of row in coppice and 6,9, and 0 seedlings per meter of row in interspace soils. These results agree with those of Wood et al. (1982), showing that emergence of crested wheatgrass seedlings is higher on coppice soils compared with interspace soils in areas of vesicular crusting. Bubus soils had significantly less coppice than Abgese and McConnel soils. Abgese, McConnel, and Bubus soils averaged 54,51 , and $42 \%$ coppice, respectively (Table 2 ). This indicates that there is an inverse relationship between amount of coppice and seedling establishment on these soils. Soil survey data collected by the SCS does not include percentage of coppice and interspace. Soils data are for interspace soils, which, in areas with vesicular crusting, are very poor for seedling establishment compared with the accompanying coppice soils.

The type of drill used significantly $(p=0.05)$ affected the number of crested wheatgrass seedlings per meter of row, but not the density of seedlings. Averaged over the 4 major soils, deep-furrow drilling resulted in 10 seedlings per meter of row whereas standard drilling resulted in 7 seedlings per meter of row. However, because of wider row spacing on the deep-furrow drill, a nonsignificant difference in seedling density of 22 and 25 seedlings per square meter resulted for the deep-furrow and standard drills. There was no significant interaction between type of drill and soil. Deepfurrow drilling resulted in the same relative seedling density as standard drilling in each soil.

\section{Downy Brome}

Downy brome is considered a major competitor with crested wheatgrass for early spring and summer moisture on western rangelands (Evans 1961, Harris and Wilson 1970). In this study, the yield of downy brome was affected by method of brush control and soils. Averaging over the 4 soils, plowing and seeding resulted in significantly $(p=0.05)$ more downy brome than spraying and seeding, while both treatments significantly increased yield of downy brome over the control areas. Burning and seeding also significantly increased yield of downy brome over the control areas. In 1979, yield of downy brome averaged 930,360 , and 30 $\mathrm{kg} / \mathrm{ha}$ in plowed and seeded, sprayed and seeded, and control areas, respectively. In 1980 , yield of downy brome was $150 \mathrm{~kg} /$ ha with burning and seeding and $5 \mathrm{~kg} / \mathrm{ha}$ in the control areas. Averaging over all treatments, the yield of downy brome was $65,61,44$, and $3 \mathrm{~kg} / \mathrm{ha}$ on McConnel, Zineb, Abgese, and Bubus soils. Downy brome yielded significantly $(p=0.05)$ less on Bubus soils than on the other soils. Generally, the coarser textured soils produced the most downy brome. However, there were no negative correlations between yield, frequency, or percent cover of downy brome and seedling establishment of crested wheatgrass on any soil. This indicates that effects of downy brome competition on crested wheatgrass establishment were overshadowed by differential effects of edaphic factors among the soils.

\section{Conclusions}

Although most Wyoming big sagebrush/grassland communities are probably not as heterogeneous in respect to landforms and soils as the one in this study, they are not as homogeneous as early range recommendations implied. Our results indicate that it is possible to differentiate soils within sagebrush/grassland communities by delineation of landforms on aerial photographs and with appropriate ground truth data. Measurements of edaphic properties of individual soils can be used to predict mortality of sagebrush by spraying or plowing and seedling establishment of crested wheat- 
grass after brush control and seeding. Soil texture, among all edaphic factors, was best correlated with mortality of Wyoming big sagebrush and seedling establishment of crested wheatgrass. It would probably be incorrect to extrapolate these results to areas with soils that are not predominantly Aridosols with vesicular crusting or areas outside the Wyoming big sagebrush community where adequate winter-spring precipitation does not occur for seedling establishment of crested wheatgrass.

Presently, land managers must subjectively use information from soil surveys to determine the relative suitability of a site for seeding. However, development of mathematical models based on quantified soil data, as in this study, would allow the land manager to make more accurate predictions of success or failure of a particular range improvement technique based on relationships with specific soil properties. More quantitative data of soils are needed before land managers can use such mathematical models. Quantitative measurements of soil hardness such as force of penetration, could prove useful in predictive models. The amount and characteristics of coppice and interspace should be included in soil surveys. Also, because surface horizons are the most variable and important to establishment of crested wheatgrass, surveys developed for making seeding recommendations should concentrate on the features and variability of these horizons. Determination of site suitability for brush control and seeding based only on soil series criteria is not adequate. Phase criteria, especially those of textures of surface soils, should be used. Characteristics of subsurface horizons should not be ignored because they may later affect yield of mature crested wheatgrass. These recommendations would also allow range scientists access to pertinent data that could be used in developing better predictive models.

\section{Literature Cited}

Anonymous. 1968. Service and parts manual for the brushland plow. US DA Forest Serv. Equip. Dev. Center, San Dimas, Calif.

Anonymous. 1971. Interim guide for rating soils according to their soil suitability for rangeland seeding-Nevada. USDA Soil Conserv. Serv., Reno, Nev.

Anonymous. 1975. Soil taxonomy. USDA Soil Conserv. Serv., Agr. Handbook No. 436 U.S. Gov. Print. Office, Washington, D.C.

Anonymous. 1976. National Range Handbook. USDA, Soil Conserv. Serv., U.S. Gov. Print. Office, Washington, D.C.

Asher, J.E., and R.E. Eckert, Jr. 1973. Development, testing, and evaluation of the deep furrow drill arm assembly for the rangeland drill. $J$. Range Manage. 26:377-379.

Black, C.A. ed. 1965a. Methods of soil analysis, part 1. Physical and mineralogical properties, including statistics of measurement and sampling. Agronomy No. 9, Amer. Soc. of Agron., Inc., Madison, Wisc.

Black, C.A. ed. 1965b. Methods of soil analysis, part 2. Chemical and microbial properties. Agronomy No. 9, Amer. Soc. of Agron., Inc., Madison, Wisc.

Bleak, A.T., and W.G. Miller. 1955. Sagebrush seedling production as related to time of mechanical eradication. J. Range Manage. 8:66-69.

Born, S.M. 1972. Late quaternary history, deltaic sedimentation, and mudlumps formation at Pyramid Lake, Nevada. Center for Water Resources Res., Desert Res. Inst., Univ. of Nevada

Bouyoucos, G.J. 1962. Hydrometer method improved for making particle size analysis of soil. Agron. J. 54:464-465.

Cook, C.W. 1963. Herbicide control of sagebrush on seeded foothill ranges in Utah. J. Range Manage. 16:190-195.

Cook, C.W., L.A. Stoddart, and P.L. Sims. 1967. Effects of season, spacing, and intensity of seeding on the development of foothill range grass stands. Utah Agr. Exp. Sta. Bull. 467.

Eckert, R.E., Jr., A.T. Bleak, J.H. Robertson, and E.A. Naphan. 1961. Responses of Agropyron cristatum, A. desertorum, and other range grasses to three different sites in eastern Nevada. Ecology 4:775-783.
Evans, R.A. 1961. Effects of differential densities of downy brome (Bromus tectorum) on growth and survival of crested wheatgrass (Agropyron desertorum) in the greenhouse. Weeds 9:216-223.

Evans, R.A., and R.M. Love. 1957. The step-point method of sampling-a practical tool in range research. J. Range Manage. 10:208-212.

Harris, G.A., and A.M. Wilson. 1970. Competition for moisture among seedlings of annual and perennial grasses as influenced by root elongation at low temperatures. Ecology 51:530-534.

Houghton, J.G., C.M. Sakamoto, and R.O. Gifford. 1975. Nevada's weather and climate. Nevada. Bur. of Mines and Geol. Spec. Pub. No. 2, Mackay School of Mines, Univ. of Nevada, Reno.

Mifinin, M.D., and M.M. Wheat. 1979. Pluvial lakes and estimated pluvial climates of Nevada. Nevada Bur. of Mines and Geol. Bull. 94.

Motts, W.S. 1970. Geology and hydrology of selected playas in western United States. U.S. Air Force Cambridge Res. Lab. Aerospace Studies, Bedford, Mass.

Nie, N.H., C.H. Hull, J.G. Jenkins, K. Steinbrenner, and D.H. Brent. 1970. Statistical package for the social sciences. McGraw-Hill, Inc. USA.

Pechanec, J.F., G. Stewart, A.P. Plummer, J.H. Robertson, and A.C. Hull, Jr. 1954. Controlling sagebrush on rangelands. USDA, Farm Bull. Nev. 2072.

Peterson, F.F. 1981. Landforms of the basin and range province. Nevada Agr. Exp. Sta. Tech. Bull. 28.

Phillips, E.A. 1959. Methods of vegetation study. Holt, Rhinehart and Winston, Inc. N.Y., N.Y.

Piemeisel, R.L., and J.C. Chamberlin. 1936. Land improvement measures in relation to a possible control of beet leafhopper and curly top. USDA, Cir. 416.

Plummer, A.P., A.C. Hull, Jr., George Stewart, and J.H. Robertson. 1955. Seeding rangelands in Utah, Nevada, southern Idaho and western Wyoming. USDA, Agr. Handb. 71.

Robertson, J.H. 1947. Season, date, and depth of planting crested wheatgrass and other grasses at lower elevations in northern Nevada. USDA Intermount. Forest and Range Exp. Sta. Res. Pap. Nó. 14.

Robertson, J.H., and P.C. Kenneth. 1943. How to reseed Nevada range lands. USDA Intermount. Forest and Range Exp. Sta. Res. Pap. 3.

Schwendiman, J.L. 1955. When, where, and how to succeed with range seeding. Crops and Soils 7:9-11.

Shown, L.M., R.F. Miller, and F.A. Branson. 1969. Sagebrush conversion to grassland as affected by precipitation, soil, and cultural practices. $\mathbf{J}$. Range Manage. 22:303-311.

Tisdale, E.W., M. Hironaka, and M.A. Fosberg. 1969. The sagebrush region in Idaho, a problem in resource management. Univ. of Idaho Agr. Exp. Sta. Bull. 512.

Vallentine, J.F. 1971. Range development and improvement. Brigham Young Univ. Press, Provo, Utah.

Wein, R.W., and N.E. West. 1971. Seedling survival on erosion control treatments in a salt desert area. J. Range Manage. 24:352-357.

Wood, M.K. 1976. The effects of vesicular horizons on emergence of grasses and shrubs. M.S. Thesis, Univ. of Nevada, Reno.

Wood, M.K., W.H. Blackburn, R.E. Eckert, Jr., and F.F. Peterson. 1978. Interrelations of the physical properties of coppice dune and vesicular dune interspace soils with grass seedling emergence. J. Range Manage. 31:189-192.

Wood, M.K., R.E. Eckert, Jr., W.H., Blackburn, and F.F. Peterson. 1982. Influence of crusting soil surfaces on emergence and estalishment of crested wheatgrass, squirreltail, thurber needlegrass, and fourwing saltbush. J. Range Manage. 35:282-287.

Young, J.A., R.E. Eckert, Jr., and R.A. Evans. 1979a. Historical perspectives regarding the sagebrush ecosystem. p. 1-13. In: The Sagebrush Ecosystem: A Symposium. Utah State Univ., Coll. of Nat. Resources, Logan, Utah.

Young, J.A. and R.A. Evans, eds. 1980. Physical, biological, and cultural resources of the Gund Research and Demonstration Ranch, Nevada. UDSA Agr. Res. Serv., Agr. Rev. and manuals. ARM-W-11.

Young, J.A., B.A. Roundy, A.D. Bruner, and R.A. Evans. 1979b. Ground sprayer for sagebrush rangelands. USDA, Agr. Res. Serv., Adv. in Agr. Tech. AAT-W-8. 